PhD Thesis Summary

\title{
Dutch-Indonesian interlanguage Psycholinguistic study on syntax
}

\author{
SUGENG RIYANTO \\ PhD Public Examination, 15 November 2011 \\ PhD in Humanities \\ Promoter: Prof. Dr. Rahayu S. Hidayat \\ Co-promoter: Dr. Kees Groeneboer \\ University of Indonesia
}

\begin{abstract}
This article focuses on the psycholinguistic study of the syntactic aspects of Dutch-Indonesian interlanguage. The study is based on the interlanguage syntax observed in an oral test given to thirty Indonesian learners of Dutch as a second language, whose purpose is to test the processability theory of Pienemann (2005a, b, c, 2007). The results of the study provide evidence for the validity of Pienemann's theory. Learners who have acquired sentences with the highest level of processing will also already have acquired sentences with a lower level of processing. The results from learners with a high level of Dutch proficiency verify the processability theory with more certainty than the results of learners with a lower proficiency. Learners tend to rely on meaning if they are not confident of their grammatical proficiency. Interlanguage is the result of the immediate need to encode in the mind concepts and ideas into the form of linguistic items, within a fraction of a millisecond, whilst the supporting means are limited, and whilst learners already have acquired a first language and possibly another language as well.
\end{abstract}

KEYWORDS

Interlanguage, processability theory, exchange of grammatical information, Dutch/Indonesian.

SUGENG RIYANTO is staff at the Faculty of Humanities, Padjadjaran University and teacher at the Dutch Language Center, Erasmus Taalcentrum Jakarta. Sugeng Riyanto may be contacted at: sugeng.riyanto@unpad.ac.id.

(C) 2012 Faculty of Humanities, University of Indonesia 


\section{INTRODUCTION}

This article is about Dutch-Indonesian interlanguage amongst Indonesians who are learning Dutch in Indonesia. The study is psycholinguistic in nature and is based on the Processability Theory (Pienemann 2006, 2007). Interlanguage is a language system that has developed in the minds of language learners that learn a second language (Richards and Schmidt 2002: 267; O'Grady, Archibald, Aronoff, and Miller 2005: 401; Wray and Bloomer 2006: 54, Tarone 2000: 182, 2006: 747). Ellis and Barkhuizen (2005) called interlanguage "the language of learners".

The research questions relate to the following: (1) types of interlanguage sentences, (2) level of language proficiency, (3) prediction of the Processability Theory; and (4) stages of interlanguage. The study challenges the prediction of the theory in terms of syntactic skills.

\section{PROCESSABILITY THEORY}

The Processability Theory (hence PT) is a theory about the development of second-language proficiency in second-language learners (L2-learners). According to the theory, L2-learners produce and understand linguistic elements that can be processed at one time by the language processor in the memory. Therefore, it is important to know how the composition of the language processor looks and how the language processor processes the L2. In this way, one can predict the development of second-language skills of learners concerning language production and comprehension (Pienemann 1998a, b, 2005a, b, c, 2006, 2007; Jordan 2004; VanPatten and Williams 2007; Alhawary 2009; Riyanto 2010).

The PT aims to form hypotheses about the universal hierarchy of different strategies in the processing of language, as regards the procedural skills necessary for the acquisition of the target language. The process is performed by a language processor in the brains of the L2 learners (Pienemann 2005a: 3). So, one can predict and verify the stages of the L2 acquisition.

The composition of the language processor is responsible for language processing in real time and is determined by psychological factors, such as the retrieval of words from the mental lexicon and working memory. Research into L2 acquisition now takes into account the language processor so that attention should also indicate the corresponding psycholinguistic factors. These psycholinguistic factors affect the processing of a language, including a second language. The PT has a hierarchy in the processing of language in the minds of language learners (processing hierarchy). This is based on the idea that an exchange occurs in the grammatical information in and between phrases in a sentence (Pienemann 1998a, 2005a). The grammatical information "third person singular" is, for instance, awarded to de kleine Peter (the little Peter) and gaat (goes) in the sentence De kleine Peter gaat naar de bakker (the little Peter goes to the bakery). They are called a congruence relation between the subject and the verb.

According to the Lexical Functional Grammar (LFG) and the theory 
of Levelt (1989) on language production, the language processor explores whether de kleine Peter and gaat have the same grammatical information. The information "third person singular" is preserved in the language processor. The verb gaat has the information "third person singular" corresponding to the grammatical information of de kleine Peter. The language processor compares the two with each other. If they match, the two phrases together form a grammatical sentence. The L2 learners should develop procedures to store and compare such grammatical information. They learn to decide whether a sentence is grammatical or not. In the sentence De kleine Peter ga naar huis (The little Peter go home), de kleine Peter has the information "third person singular" but the verb ga (go) for "first person singular" does not. The two phrases do not match. In Dutch, the subject and the verb agree in person and number. The sample sentence is a sentence in interlanguage. The L2learner that produces the sentence has not acquired "the agreement between the subject and the verb"-rule. That the L2-learner chooses ga instead of gaan (to go) is an achievement, but it is not enough.

The same principle applies to the information within a phrase, for example, twee boeken (two books). The information "plural" is present in twee (two), and boeken (books). In Dutch, the grammatical information has to match to form a nominal phrase. Beginning Indonesian L2 learners of Dutch still produce twee book (two book). In LFG, this process is called "feature unification".

The above examples show the processing hierarchy seen in the PT. The grammatical information within a sentence is compared with the information between phrases. Within each phrase, the grammatical information of one word must match with the other word in the same phrase, and this is done prior to the formation of a sentence.

The process of grammatical conformity takes place in a certain sequence. This is the principle of the processing hierarchy. The nominal phrase is assembled before the verbal phrase. Then, the sentence is composed. A word is a category, for instance, noun or verb, and the categorical process is the gathering place for the grammatical information such as "singular" and "past". Therefore, the categorical procedure is processed before the procedure of the nominal phrase. The first version of the processing hierarchy is as follows (Pienemann 1998a; Pienemann, Di Biase, and Kawaguchi 2005):

a. No proocedure: for example, producing a simple word ja (yes).

b. Categorical procedure: for example, adding a past-tense morpheme -te to a verb as werkte (worked).

c. Nominal phrase: for example, matching plurality as in twee woorden (two words).

d. Verbal phrase procedure: for example, moving an adverb out of the verb phrase to the front of a sentence: as in, Morgen ga ik naar Leiden (Tomorrow I go to Leiden).

e. Sentence procedure: such as, subject-verb agreement: $i k$ ga (I go), hij gaat (he goes), wij gaan (we go). 
f. Subordinate clause procedure: such as, use of subjunctive in subordinate clauses triggered by information in a main clause: Ik zeg dat hij morgen naar Leiden gaat (I say that I go to Leiden tomorrow).

The basic hypothesis underlying PT is that learners develop their grammatical inventory following this hierarchy for two reasons: (a) the hierarchy is implicationally ordered, that is, every procedure is a necessary prerequisite for the next procedure; and (b) the hierarchy mirrors the time-course in language generation (Pienemann 2007: 141). Therefore, the learner has no choice other than to develop along this hierarchy. Phrases cannot be assembled without words being assigned to categories such as "noun" and "verb," and sentences cannot be assembled without the phrases they contain, and so forth. The fact that learners have no choice in the path that they take in the development of processing procedures follows from the time-course of language generation and the design of processing procedures. For example, if learners are in the third stage of the processing (they can only exchange information in a phrase), they will find problems to produce a sentence because they have to exchange grammatical information between phrases.

\section{THE INFORMANTS AND LANGUAGE DATA}

The informants consisted of students of Dutch Department, University of Indonesia, from the second, fourth, sixth, and eighth semesters. In May 2007, they took the exam het Certificaat Nederlands als Vreemde Taal (CNaVT) (the Certificate of Dutch as a Foreign Language). The students were grouped according to the profiles of the CNaVT exam they took, namely PTIT (tourist profile, A2), PMT (social profile, B1), and PTHO (higher education profile, B2). There were ten informants eligible for each profile. The choice was based on their test results: weak, average, and strong informants.

The data consisted of spoken material for the CNaVT exam, called C-section. The examiners of the exam in May 2007 were some lectures of Dutch Department of University of Indonesia and teachers of Erasmus Taalcentrum (the Erasmus Dutch Language Centre) Jakarta. The recording restarted manually and recorded at the headquarters of the CNaVT at the Katholieke Universiteit Leuven in late September 2009.

The theory makes use of so-called implicational scale to present the results of the research (Pienemann 1998a and 2005b). The scale can predict the development of syntactic skills (skills in word order of sentences) of the $\mathrm{L} 2$ learners. The $\mathrm{V}$-end construction, for example, is the hardest structure to process in the minds of language learners in comparison with other structures. If they have acquired the construction (in the column you see a " + "), they have also acquired the other simpler structures. The following columns must also stand the plus sign. The plus sign means that the structures are acquired (at least $70 \%$ good). The interlanguage is under development, so one does not strive for a higher percentage. 
RESULTS AND DISCUSSION

\section{THE ACQUISITION OF STRUCTURES}

\section{One word construction}

The construction consists of only one word. All informants mastered this simplest processable structure. In the construction, they just processed words and did not need to process grammatical elements. They only needed grammatical elements if they produced at least a word phrase. They had, therefore, been informed that a sentence consisted of at least one $S$ (subject) and a FV (finite verb). They were adult L2 learners who have learned almost certainly one other foreign language. They have been taught Dutch intensively in the Department by experienced lecturers. If they uttered a one word construction that was usually: ja/nee (yes/no), this was normal for the answer of a yes/no question.

\section{Canonical construction}

The canonical structure has the following sequence: S-FV (O/object) (Adj(unct)). The sentence has at least one $\mathrm{S}$ and an FV. This construction is more difficult to process than the former. The language processor in the mind of the learner has to process at least a nominal phrase (for the syntactic function $S$ and $O$ ) and a verbal phrase (the predicate). The language processor knows how to share the grammatical information between phrases: first within the phrases and then between the phrases. The word order is the simplest, because the agent is prior to the act (in the form of a verb), while the patient follows. That order is unmarked. Therefore, the informants could process the canonical construction.

In interlanguage (IL) sentence (1) the informant tried to say that her sweater shrunk. Apparently, she did not know the word and wrongly chose the word verkleinen (to make small, to reduce). It would be better to choose kleiner worden (to become smaller).

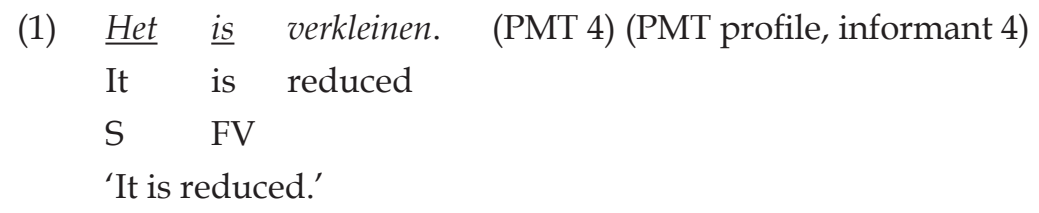

\section{Adv-construction}

The structure of Adv-construction is: Adj/O-S-FV/P-(O)-(Adj). The processing of this construction is harder than the canonical because there is markedness. In the first place, the standing part of the sentence is not $S$, but for example, an Adj or an $\mathrm{O}$. There is a matter of topicalization. The structure is an interlanguage construction because the $\mathrm{S}$ remains before the FV/P. The correct order for that structure would be the Inv-structure, namely the inversion sentences in which the $S$ takes place behind the FV/P. The informants managed to have the 
Adv-construction. Indonesian has such an order. Below, you see an example of the IL-sentence:

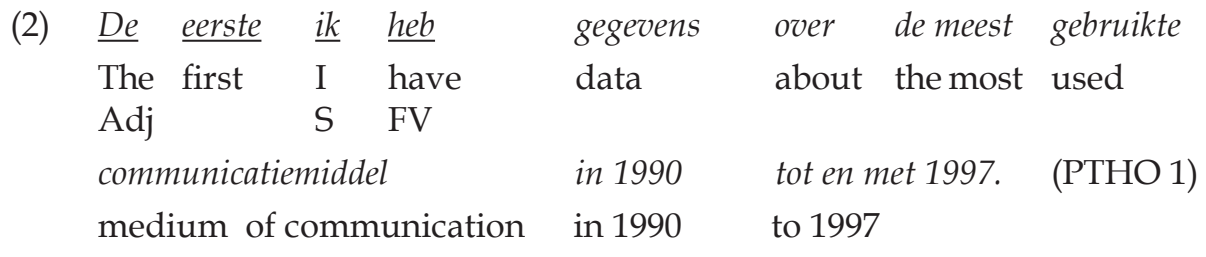

'The first I have information about the most used medium of communication in 1990 to 1997.'

\section{Sep-construction}

The sentence in the separable structure has more than one verb. The predicate consists of an FV and one or more verbs (as rest van het gezegde "the rest of the predicate" (RP)). As regards meaning, the verbs stand together as a group, but in the sentence, they are separated. The FV stands beside the S. The meaning and the form do not correspond and, therefore, the construction is more difficult to handle than the previous structures. As an example, the following is an IL-sentence:

(3) $\begin{array}{lllll}\text { Vandaag } & \underline{\text { moet }} & \text { ik } & \frac{\text { fietsen }}{\text { Today }} \text { must } & \text { in zee. (PTIT 2) } \\ \text { cycle in sea. }\end{array}$
Adj FV S RP
'Today I have to cycle in the sea.'

The FV and RP are separated but not so far. It is normal if the RP stands back in the sentence. One never cycles in the sea. The IL-sentence (3) can be changed, for example, in sentence (3a).

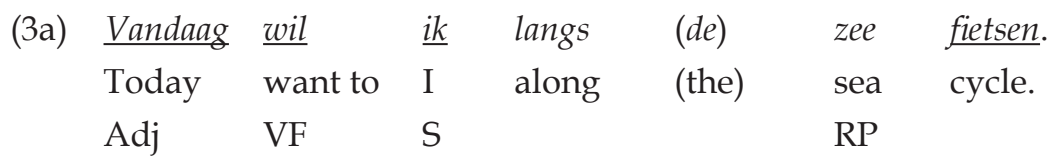

'Today I want to cycle along the sea (the beach).'

Sentence (4) is an interlanguage by the use of interjection $j a$ (yes). In spoken Indonesian, the use of interjections is very normal. Indo-Dutch often use interjections in their Dutch to create a special atmosphere. In Dutch, one can change the IL-sentence (4) as in example (4a).

$\begin{array}{lllllll}\text { (4) Dus } & \underline{i k} & \underline{\text { kan }} & \text { niet } & \underline{\text { ruilen, }} & \text { ja. } & \text { (PMT 1) } \\ \text { So } & \text { I } & \text { can } & \text { not } & \text { swap, yes } & \\ & \text { S } & \text { FV } & & \text { RP } & & \end{array}$

'So I may not swap?' 


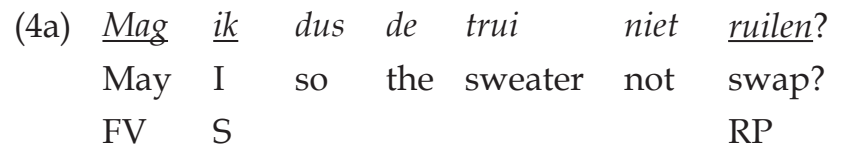

'So I cannot swap the sweater?'

\section{Inv-construction}

This construction is almost the same as the Adv-construction. The difference lies in the position of the S. In the Adv-construction S stands before the FV, and in the Inv-construction the $\mathrm{S}$ is behind the FV. The Adv-construction is always an IL-sentence, while the Inv-construction is an acceptable Dutch sentence. Inv stands for inversion. The processing of the Inv-construction is more difficult than the Sep-construction because one of the verbs of the verbal phrase, for example an adjunct, appears in the first place in the sentence, and the $\mathrm{S}$ should move to the location behind the FV. There is a matter of topicalization. The word order of sentence (5) is structurally correct, but it is still an IL-sentence because it needs some structural changes to become a good Dutch sentence (5a).

$\begin{array}{llllll}\text { (5) } \frac{\text { In }}{\text { In }} \frac{\text { de }}{\text { slaapkamer }} & \frac{\text { staat }}{\text { bedroom }} & \frac{\text { een }}{\text { stand }} & \frac{\text { twee }}{\text { a }} & \frac{\text { bed. }}{\text { two }} \text { bed } \\ \text { Adj } & & \text { FV } & & \text { S } & \end{array}$

'The bedroom has a double bed.'

$\begin{array}{llllll}\text { (5a) } \frac{\text { In }}{\text { In }} \frac{\text { de }}{\text { slaapkamer }} & \frac{\text { staan }}{\text { bedroom }} & \frac{\text { er }}{\text { stand }} & \frac{\text { twee }}{\text { there }} & \text { bedden. } \\ \text { two } & \text { bed } \\ \text { Adj } & & \text { FV } & & \mathrm{S} & \end{array}$

'In the bedroom there are two beds.'

Sentence (6) has an Adv-construction because the $\mathrm{S}$ stands before the FV. The correct sequence is seen at the inversion sentence (6a).

(6) Misschien het is toch genoeg... (PTHO 6)

May be it is still enough

Adj S VF

'Maybe it's still enough...'

(6a) Misschien is $\underline{\text { het }}$ toch genoeg.

May be is it still enough

Adj VF $S$

'Maybe it's still enough.' 


\section{$6 V$-end construction}

This subordinate construction is in PT the most difficult construction to process. Semantically, the subject and predicate belong together but in the subclause, they are far apart. The wide separation of phrases is a difficult process in memory. The Indonesian language does not have the phenomenon, and neither does English. Indonesian is an SVO language, and informants have learned English, which is an SVO language, too. There is SVO fanaticism in the minds of Indonesians. In a Sep-structure, a phrase is separated, while in a V-end construction two phrases are separated. Sometimes, the informants were able to separate the subject and predicate, but the spoken sentence was not always a good Dutch sentence as in (7). In Indonesian, naar daar (to there, Ind. ke sana) would be considered normal.

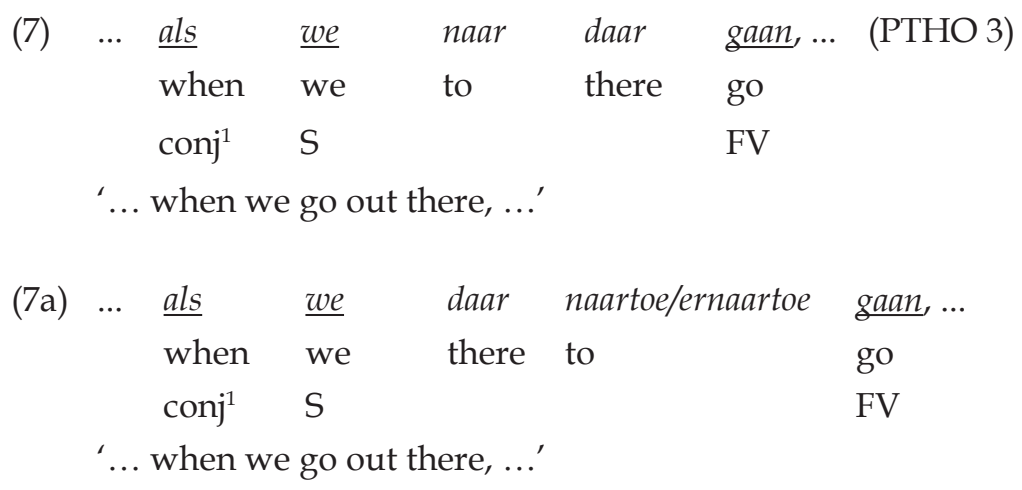

A sub-clause (8) begins with a conjunction and, thus, the FV must stand back near the rest of the predicate and far from the subject. The FV is kunnen instead of kan because the subject is de mensen (the people). If everything is $\mathrm{OK}$, then one gets a sentence (8a). The Sep-construction may not have occurred in a subordinate clause, but the informant PTHO 4 did not follow the rule. He chose the Sep-construction. He had also done this with two other IL-sentences.

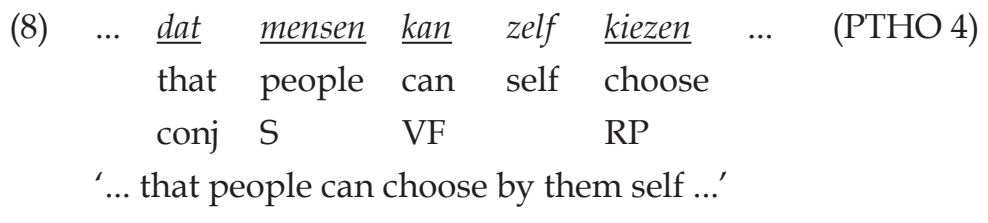

$\begin{array}{rllllll}\text { (8a) ... } & \frac{\text { dat }}{\text { that }} \text { de } & \frac{\text { mensen }}{\text { people }} \text { zelf } & \frac{\text { kunnen }}{\text { can }} & \frac{\text { kiezen }}{\text { choose }} & \ldots \\ \text { conj } & & \mathrm{S} & & \mathrm{VF} & \mathrm{RP} & \end{array}$

'... that people can choose by them self ...'

$1 \quad$ conj $=$ conjunction. 
THE IMPLICATIONAL SCALE

In Table 1, we see the result of the scale of implicational PTIT.

\begin{tabular}{|l|l|l|l|l|l|l|l|l|l|l|}
\hline Stage & 1 & 2 & 3 & 4 & 5 & 6 & 7 & 8 & 9 & 10 \\
\hline 6. V-end & - & - & - & $/$ & $/$ & $/$ & - & - & - & - \\
\hline 5. Inv & + & - & - & - & - & - & + & + & - & + \\
\hline 4. Sep & $/$ & $/$ & + & + & + & + & + & + & $/$ & + \\
\hline 3. Adv & + & + & + & + & + & + & + & + & + & + \\
\hline 2. Can & + & + & + & + & + & + & + & + & + & + \\
\hline 1. Word & + & + & + & + & + & + & + & + & + & + \\
\hline
\end{tabular}

Explanation: 1 = informant PTIT 1; 2 = informant PTIT 2; and so on Table 1. The implicational scale PTIT.

Table 1 shows that four informants could manage to deal with the Invconstruction. Informant PTIT 1 had acquired Inv, but not Sep because the informant produced less than four Sep-constructions (hence see "/"), so it could not be determined whether he had control on the construction. If he did not master the structure one sees " - ", and when one sees under a plus mark a minus mark then the Processability Theory would be false. The mark "/" has put the theory into safety.

The informants PMT performed better than PTIT. Six informants could process the Inv and Sep. The implicational scale was well filled in with the plus marks. Informant PMT 1 did something strange because he/she produced less than four sentences with an Adv-construction, so one cannot determine his mastery of the structure. The informant had also put the theory into safety. In the implicational scale of PMT, there are four "/" marks.

The implicational scale of the PTHO is best filled. One sees no "/" anymore. The PTHO informants produced more sentences than the other groups of informants. Their performance was still almost the same as the PMT. They could process the Sep-construction well. Five informants could manage the Inv-construction, while one informant could control the V-end.

\section{THE ORDER OF ACQUISITION}

In Table 2 one can see the position of each informant regarding their syntactic skills. It takes into account that they produce at least four sentences in each construction.

\begin{tabular}{|l|l|l|l|l|l|l|l|}
\hline No. & Informant & Percent & Semester & No. & Informant & Percent & Semester \\
\hline 1 & PTHO 1 & 86,53 & 4 & 16 & PMT 6 & 59,26 & 4 \\
\hline 2 & PMT 9 & 79,17 & 6 & 17 & PMT 10 & 53,68 & 6 \\
\hline 3 & PTHO 9 & 74,99 & 6 & 18 & PTIT 5 & 51,67 & 2 \\
\hline
\end{tabular}




\begin{tabular}{|l|l|l|l|l|l|l|l|}
\hline No. & Informant & Percent & Semester & No. & Informant & Percent & Semester \\
\hline 4 & PMT 5 & 74,44 & 4 & 19 & PMT 4 & 50 & 6 \\
\hline 5 & PTHO 8 & 72,22 & 4 & 20 & PTHO 7 & 49,72 & 6 \\
\hline 6 & PMT 3 & 71,69 & 6 & 21 & PTIT 3 & 49,17 & 2 \\
\hline 7 & PTHO 5 & 69,87 & 4 & 22 & PTHO 4 & 45,83 & 4 \\
\hline 8 & PTIT 7 & 66,89 & 6 & 23 & PTIT 6 & 43,33 & 2 \\
\hline 9 & PTIT 10 & 65,09 & 6 & 24 & PTIT 4 & 38,89 & 2 \\
\hline 10 & PTIT 8 & 65 & 2 & 25 & PTHO 10 & 38,15 & 4 \\
\hline 11 & PMT 7 & 62,50 & 2 & 26 & PMT 2 & 35,35 & 4 \\
\hline 12 & PTHO 6 & 62,33 & 6 & 27 & PMT 1 & 33,33 & 6 \\
\hline 13 & PTHO 3 & 62,24 & 8 & 28 & PTIT 2 & 27,94 & 4 \\
\hline 14 & PMT 8 & 61,11 & 8 & 29 & PTIT 1 & 25 & 2 \\
\hline 15 & PTHO 2 & 60 & 6 & 30 & PTIT 9 & 19,85 & 4 \\
\hline
\end{tabular}

Table 2. Construction percentage Sep, Inv, and V-End of informants PTIT, PMT, and PTHO.

Six informants (three PTHO and three PMT) could control the three constructions for more than $70 \%$. They were best suited to the processing of the three constructions. Among them, an informant PTIT was not present. In the best of ten, there were three informants PTIT. The informants PTIT dominated the ten lowest percentages. It included two informants PTHO and two informants PMT. In this case, the correct order of the subject and FV/RP is the only consideration.

\section{CONCLUSION}

The result of this study has proven the sustainability of the Processability Theory. Learners who have mastered the hardest processable sentences also mastered the easier processable sentences. The results of learners with good syntactic skills support the theory with more certainty than the results of learners with low syntactic skills. The results are consistent with the study of Kawaguchi (2005) for Japanese-English, Mansouri (2005) for Arabic-English, Zhang (2005) for Chinese-English, and Håkanson (2005) for Swedish-Syrian, Swedish-Karamanji, Swedish-Turkish, and Swedish-Arabic by children.

The informants controlled one word construction, canonical construction, and Adv-construction. They have been taught Dutch for a minimum of 1.5 semesters (intensive) and maximum of 7.5 semesters. Indonesian also has the three constructions. In a one-word construction, they did not take into account the exchange of grammatical information. There is a direct relationship between the form and meaning so that the informants processed the word easier. In other words, there is a mapping between the form and meaning.

The adjustment of the grammatical information between words and between phrases remained a stumbling block to the informants. At the 
interlanguage sentences, grammatical information was not always shared. To make good Dutch sentences, they must take into account the proper exchange of grammatical information. At the initial stage of interlanguage, the language learners further paid more attention to the meaning than the grammar. The meaning had to be expressed by means of linguistic elements and grammar made the organization of meaning efficient and effective. Riyanto (1990) examined that Indonesian speakers of Dutch looked at meaning more than at grammar, while the native speakers of Dutch would do the opposite.

The Processability Theory is too safe as it determines the rate of $70 \%$ as a minimum control in Sep, Inv, and V-end. With such a percentage, it is difficult to put the theory to challenge. The theory should be set at a higher percentage, for instance $80 \%$. With a higher percentage, the result of the study may look different. The theory fits with elementary language learners. For advanced or near-native learners, one should consider a much higher percentage, for example $90 \%$. This is a challenge for further research.

Investigations into interlanguage inspire people not to negatively judge language products of second language learners. Here negative reactions to interlanguage do not fit either. The lecturers and teachers certainly should not discourage learners; on the other hand, they should encourage learners correctly. The sentences they produced had a complicated process instilled into their minds, while they had limited time to process everything. Their vocabulary was limited, and they also knew little grammatical rules. The interlanguage is the result for the need of learners to encode ideas and concepts in linguistic elements at a fast pace as they had limited vocabulary and a restricted grammar; also, because they have already mastered a first language or a foreign language. Anything that they could say in the second language, whatever the form, must be accepted as a great achievement as this process does not occur easily.

\section{REFERENCES}

Alhawary, M.T. 2009. "Speech processing prerequisites or L1 transfer? Evidence from English and French L2 learners of Arabic", Foreign Language Annals 42(2): 367-391.

Ellis, R. and G. Barkhuizen. 2005. Analysing learner language. Oxford: Oxford University Press.

Håkanson, G. 2005. "Similarities and differences in L1 and L2 development", in: M. Pienemann (ed.), Cross-linguistic aspects of Processability Theory, pp. 179-197. Amsterdam/Philadelphia: John Benjamins.

Jordan, G. 2004. Theory construction in second language acquisition. Amsterdam: John Benjamins.

Kawaguchi, S. 2005. "Argument structure and syntactic development in Japanese as a second language", in: M. Pienemann (ed.), Cross-linguistic aspects of Processability Theory, pp. 253-298. Amsterdam/Philadelphia: John Benjamins.

Levelt, W.J.M. 1989. Speaking: from intention to articulation. Cambridge, MA: MIT Press. 
Mansouri, F. 2005. "Agreement morphology in Arabic as a second language," in: M. Pienemann (ed.), Cross-linguistic aspects of Processability Theory, pp. 117-153. Amsterdam/Philadelphia: John Benjamins.

O'Grady, W., J. Archibald, M. Aronoff, and J. Rees Miller. 2005. Contemporary linguistics; An introduction. New York: Bedfort/St. Martins.

Pienemann, M. 1998a. Language processing and second language development; Processability Theory. Amsterdam/Philadelphia: John Benjamins.

Pienemann, M. 1998b. “Developmental dynamics in L1 and L2 acquisition; Processability Theory and generative entrenchment", Bilingualism; Language and Cognition 1(1): 1-20.

Pienemann, M. 2005a (ed.). Cross-linguistic aspects of Processability Theory. Amsterdam/Philadelphia: John Benjamins.

Pienemann, M. 2005b. "An introduction to Processability Theory", in: M. Pienemann (ed.), Cross-linguistic aspects of Processability Theory, pp. 1-60. Amsterdam/Philadelphia: John Benjamins.

Pienemann, M. 2005c. "Discussing PT", in: M. Pienemann (ed.), Cross-linguistic aspects of Processability Theory, pp. 61-83. Amsterdam/Philadelphia: John Benjamins.

Pienemann, M. 2006. "Language processing capacity", in: C.J. Doughty and M.H. Long (eds), The handbook of second language acquisition, pp. 679-714. Maden, MA: Blackwell.

Pienemann, M. 2007. "Processability theory", in: B. VanPatten and J. Williams (eds), Theories in second language acquisition; An introduction, pp. 137-154. London/Mahwah, NJ: Lawrence Erlbaum.

Pienemann, M., B. Di Biase, and S. Kawaguchi. 2005. “Processability, typological distance and L1 transfer", in: M. Pienemann (ed.), Cross-linguistic aspects of Processability Theory, pp. 85-116. Amsterdam/Philadelphia: John Benjamins.

Richards, J.C. and R. Schmidt. 2002. Longman Dictionary of Language Teaching and Applied Linguistics. Harlow, London: Pearson Education Limited.

Riyanto, S. 1990. "Syntactische en semantische middelen bij de interpretatie van Nederlandse zinnen". MA thesis Universiteit Leiden.

Riyanto, S. 2010. “Teori keterprosesan bahasa". Paper, Seminar Nasional Hasil Sandwich Dikti 2009, Jakarta, 12 April.

Tarone, E. 2000. "Still wrestling with 'context' in interlanguage theory", Annual Review of Applied Linguistics 20: 182-198.

Tarone, E. 2006. "Interlanguage”, in: K. Brown (ed.), Encyclopaedia of Language and Linguistics, pp. 747-752. Oxford: Elsevier.

VanPatten, B. and J. Williams (eds). 2007. Theories in second language acquisition; An introduction. New York/London: Routledge.

Wray, A. and A. Bloomer. 2006. Projects in linguistics; A practical guide to researching language. New York/London: Hodder Arnold.

Zhang, Y. 2005. "Processing and formal instruction in the L2 acquisition of five Chinese grammatical morphemes", in: M. Pienemann (ed.), Cross-linguistic aspects of Processability Theory, pp. 155-177. Amsterdam: John Benjamins. 